\title{
Hemoglobinopathies in newborns in the southern region of the Triângulo Mineiro, Brazil. Cross-sectional study
}

\author{
Hemoglobinopatias em recém-nascidos na região sul do Triângulo Mineiro, Brasil. \\ Estudo transversal
}

\author{
Aline Menezes Carlos', Renata Andréia Volpe Souza", Bruna Maria Bereta de Souza"l, Gilberto de Araujo Pereiralv, \\ Sebastião Tostes Júnior ${ }^{v}$, Paulo Roberto Juliano Martins ${ }^{\mathrm{v}}$, Helio Moraes-Souza ${ }^{\mathrm{vI}}$ \\ Hospital de Clínicas, Universidade Federal do Triângulo Mineiro (HC-UFTM), Uberaba, Minas Gerais, Brazil
}

'MSc. Doctoral Student in the Health Sciences Program, Universidade Federal do Triângulo Mineiro (UFTM), Uberaba, Minas Gerais, Brazil. "PhD. Researcher at the Health Sciences Program, Universidade Federal do Triângulo Mineiro (UFTM), Uberaba, Minas Gerais, Brazil. 'BSC. Master's Student in the Health Sciences Program, Universidade Federal do Triângulo Mineiro (UFTM), Uberaba, Minas Gerais, Brazil. IvphD. Adjunct Professor Il, Biostatistics Section, Department of Nursing, Universidade Federal do Triângulo Mineiro (UFTM), Uberaba, Minas Gerais, Brazil.

vMD. Adjunct Professor, Forensic Medicine Section, Department of Social Medicine, Universidade Federal do Triângulo Mineiro (UFTM), Uberaba, Minas Gerais, Brazil.

"MD. Associate Professor IV, Hematology and Hemotherapy Section, Department of Medicine, Universidade Federal do Triângulo Mineiro (UFTM), Uberaba Regional Blood Center Coordinator/Hemominas Foundation, Uberaba, Minas Gerais, Brazil.

VIIMD. Full Professor of the Hematology and Hemotherapy Section, Department of Medicine, Universidade Federal do Triângulo Mineiro (UFTM), Uberaba, Minas Gerais, Brazil.

\section{KEY WORDS:}

Fetal blood.

Hemoglobinopathies.

Neonatal screening.

Thalassemia.

Anemia, hemolytic.

\section{PALAVRAS-CHAVE:}

Sangue fetal.

Hemoglobinopatias

Triagem neonatal.

Talassemia.

Anemia hemolítica.

\begin{abstract}
CONTEXT AND OBJECTIVE: Hemoglobinopathies are among the commonest and most widespread genetic disorders worldwide. Their prevalence varies according to ethnic composition and/or geographical region. The aim of this study was to investigate the presence of hemoglobinopathies and their association with ethnicity among 1,004 newborns, to confirm the guideline of the Brazilian National Neonatal Screening Program.

DESIGN AND SETTING: Cross-sectional study conducted in a public referral hospital in the Triângulo Mineiro region, Minas Gerais, Brazil.

METHODS: Qualitative assessment of hemoglobin was performed through electrophoresis on cellulose acetate: at alkaline $\mathrm{pH}$ to identify the hemoglobin $(\mathrm{Hb})$ profile and at acid $\mathrm{pH}$ to differentiate $\mathrm{Hb} \mathrm{S}$ from $\mathrm{Hb}$ $\mathrm{D}$ and $\mathrm{Hb} \mathrm{C}$ from $\mathrm{Hb}$ E and others that migrate to similar positions at alkaline $\mathrm{pH}$. Neutral $\mathrm{pH}$ was used to detect $\mathrm{Hb}$ Bart's identified in alpha thalassemia (a-thal). The elution method after electrophoresis was used to quantitatively assess hemoglobins.

RESULTS: There was predominance of a-thal, with 105 cases (10.46\%), followed by $\mathrm{Hb}$ S with 61 cases (6.08\%, comprising $46 \mathrm{Hb}$ AS, $2 \mathrm{Hb}$ SS and $13 \mathrm{Hb}$ S/a-thal), 9 cases (0.9\%) of Hb AC and 6 cases (0.6\%) suggestive of beta thalassemia ( $\beta$-thal). The frequency of hemoglobinopathies was significantly higher among Afro-descendants.

CONCLUSIONS: These findings corroborated of the National Neonatal Screening Program for diagnosing sickle cell disease and $\mathrm{Hb} \mathrm{C}, \mathrm{Hb} \mathrm{D}, \mathrm{Hb} \mathrm{E}$ and $\beta$-thal hemoglobinopathies.
\end{abstract}

\section{RESUMO}

CONTEXTO E OBJETIVO: As hemoglobinopatias estão entre as alterações genéticas mais comuns e mundialmente difundidas, variando conforme a composição étnica e/ou geográfica. Nosso objetivo foi verificar a incidência de hemoglobinopatias por métodos de triagem laboratorial e sua associação com a etnia em 1.004 recém-nascidos.

TIPO DE ESTUDO E LOCAL: Estudo transversal; realizado em um hospital público de referência do Triângulo Mineiro, Minas Gerais, Brasil.

MÉTODOS: Avaliação qualitativa das hemoglobinas foi realizada por eletroforese em acetato de celulose: em pH alcalino para identificação do perfil hemoglobínico, em pH ácido para diferenciação das Hb S da $\mathrm{Hb}$ D e Hb C da Hb E, e outras que migrem em posições semelhantes em pH alcalino e em pH neutro para deteç̧ão de Hb Bart's, identificada na talassemia alfa (a-thal); e avaliação quantitativa das hemoglobinas pelo método de eluição após eletroforese.

RESULTADOS: Houve predomínio da a-thal, com 105 (10,46\%) casos, seguida da Hb S, com 61 casos (6,08\% - 46 Hb AS, 2 Hb SS e 13 Hb S/a-thal), 9 casos (0,9\%) de Hb AC e $6(0,6 \%)$ sugestivos de betatalassemia ( $\beta$-thal). A incidência de hemoglobinopatias foi significantemente maior em afrodescendentes. CONCLUSÕES: Esses achados reforçam a importância do Programa Nacional de Triagem Neonatal para o diagnóstico das síndromes falciformes e hemoglobinopatias C, D, E e $\beta$-thal e robustecem os dados da literatura sobre a necessidade da pesquisa da a-thal em sangue de cordão (não identificada pelo Programa Nacional) e em pacientes com anemia microcítica não responsivos à ferroterapia. 


\section{INTRODUCTION}

Hemoglobinopathies are among the commonest genetic disorders throughout the world. They include a complex group of inherited forms of anemia that are correlated with significant morbidity, and manifest at different levels of severity from barely perceptible to lethal. They are caused by mutations that affect genes that coordinate the synthesis of the globin chains of hemoglobin $(\mathrm{Hb})$, thereby resulting in absence or reduced synthesis (thalassemia and hereditary persistence of fetal hemoglobin) or structural changes (sickle cell disease, $\mathrm{Hb} \mathrm{C}, \mathrm{Hb} \mathrm{D}$ and $\mathrm{Hb} \mathrm{E}$, among others). ${ }^{1,2}$

Sickle cell disease and thalassemia are among the commonest hemoglobinopathies. These diseases may occur in isolation or together and cause a wide range of disorders of varying severity. There are five main categories of disorders associated with severe phenotypes, for which diagnosis during pregnancy or soon after birth and genetic counseling is usually indicated. These include thalassemia major (co-inheritance of two mutations of the beta chain); sickle cell syndromes (Hb S, Hb SS, Hb SC, Hb S/thalassemia, $\mathrm{Hb}$ SD, Hb $\mathrm{SO}^{\text {Arab }}, \mathrm{Hb}$ Lepore and $\mathrm{Hb} \mathrm{SE}$ ); $\mathrm{Hb}$ E/thalassemia (co-inheritance of mutations for thalassemia with $\mathrm{Hb} \mathrm{E}$ ); $\mathrm{Hb} \mathrm{H}$ disease; and $\mathrm{Hb}$ Bart's hydrops fetalis [homozygous for alpha thalassemia ( $\alpha$-thal) genotype --/--].1,3

The prevalence of hemoglobinopathies varies according to the region and the ethnic composition of the population. In some countries in Europe, Africa and Asia, where there is high incidence of hemoglobinopathies, it is a public health concern, considering that thousands of children are born with these genetic disorders annually. About 50 to $80 \%$ of children with sickle cell disease and 50,000 to 100,000 children with beta thalassemia ( $\beta$-thal) major die every year. ${ }^{4-6}$

In Brazil, data on the "Guthrie test" from the National Newborn Screening Program, which was introduced in 2001, indicate frequencies of $0.03 \%$ for $\mathrm{Hb}$ SS, $3.7 \%$ for $\mathrm{Hb} \mathrm{AS}, 0.02 \%$ for $\mathrm{Hb} \mathrm{SC}, 0.0003 \%$ for $\mathrm{Hb} \mathrm{SD}$ and $0.005 \%$ for $\mathrm{Hb} \mathrm{S} / \beta$-thal. The highest prevalence in Bahia, followed by Rio de Janeiro, Minas Gerais, Maranhão, Pernambuco and Goiás. ${ }^{7}$ These data, similar to those published by the Research Center for Diagnostic Support in Minas Gerais, ${ }^{8}$ show the limitations of high performance liquid chromatography (HPLC), the screening method currently used in this country, for identifying patients with one or two genes for $\alpha$-thal and $\beta$-thal. This is due to the high proportion of $\mathrm{Hb} \mathrm{F}\left(\alpha_{2} \gamma_{2}\right)$ at birth, which during the child's development will be substituted by $\mathrm{Hb} \mathrm{A}\left(\alpha_{2} \beta_{2}\right)$ and $A_{2}\left(\alpha_{2} \delta_{2}\right)$. The screening focuses on diagnosing sickle cell diseases, $\mathrm{Hb}$ $\mathrm{D}, \mathrm{Hb} \mathrm{E}, \beta$-thal (intermediate and major) and $\mathrm{Hb} \mathrm{H}$ disease. Therefore, the minor and asymptomatic forms, which are the most prevalent presentations of $\alpha$-thal and $\beta$-thal, are not usually diagnosed.

With specific regard to thalassemia, some studies have indicated prevalence rates between $0.5 \%$ and $6.6 \%$ in the northern region of Brazil, ${ }^{9}$ between $2.5 \%$ and $19.7 \%$ in the northeast, ${ }^{10}$ between $0.7 \%$ and $6.6 \%$ in the central-western region, ${ }^{11}$ between $0.7 \%$ and $9.48 \%$ in the southeast ${ }^{12}$ and between $0.2 \%$ and $4.44 \%$ in the south. ${ }^{13}$

Detection of carriers of these genetic changes is extremely important for public health, since all levels of the healthcare system are involved due to the high prevalence and the chronic nature of the resulting diseases, with wide-ranging clinical variations. ${ }^{4}$ Data on the incidence and epidemiology of hemoglobinopathies have been published for several Brazilian regions. However, apart from newborn screening and with the limitations already highlighted, no study has been conducted to report these figures in the Triângulo Mineiro region.

\section{OBJECTIVE}

This study aimed to investigate the prevalence of hemoglobinopathies in newborns, along with any associations with ethnicity, at a hospital in the southern region of the Triângulo Mineiro region, Minas Gerais, Brazil.

\section{METHODS}

This was a cross-sectional observational study using a quantitative approach, conducted among babies born in one public university hospital. The study was approved by the institution's Research Ethics Committee (\#1836/2010).

Among the 1,330 live births between September 2011 and January 2013, those for whom written consent was given were included in this study. Umbilical cord blood samples were collected in a tube containing $1.5 \mathrm{mg} / \mathrm{ml}$ of ethylenediamine tetraacetic acid (EDTA) and were sent to a laboratory for processing. Newborns with insufficient blood for testing were excluded and thus only 1,004 newborns were eligible for the study.

Sociodemographic and gestational data on all the newborns were gathered and documented on paper and in a database. The data gathered included name, parent's telephone number, place of origin, family history of hemoglobinopathies, gender, ethnic origin and test results.

The ethnic backgrounds of each participant and their ancestors were evaluated. In relation to the participants, ethnicity was subjectively characterized according to race, as established by the Brazilian Institute for Geography and Statistics (IBGE). ${ }^{15}$ The ethnicity of ancestors was ascertained by asking the participants and/or their guardians about the ethnic origin of the previous two generations (parents and grandparents) 
of the participant's family. Thus, three ethnic groups were established: African descendants, European descendants and unknown ancestry.

The investigation of hemoglobinopathies used the following laboratory tests: $\mathrm{Hb}$ electrophoresis on cellulose acetate at $\mathrm{pH}$ 8.6 to identify abnormal hemoglobin profiles; electrophoresis on agar phosphate at $\mathrm{pH} 6.2$ to differentiate between $\mathrm{Hb} \mathrm{S}$ and $\mathrm{Hb} \mathrm{D}, \mathrm{Hb} \mathrm{C}$ and $\mathrm{Hb} \mathrm{E}$ and others that migrate to a similar position at $\mathrm{pH}$ 8.6; electrophoresis on cellulose acetate at neutral $\mathrm{pH}$ to detect $\mathrm{Hb} \mathrm{H}$ and $\mathrm{Hb}$ Bart's suggestive of $\alpha$-thal; quantification of $\mathrm{Hb} \mathrm{A}, \mathrm{Hb}$ Fetal and $\mathrm{Hb} \mathrm{A}_{2}$; and cytological investigation of $\mathrm{Hb} \mathrm{H}$ inclusion bodies and Heinz bodies after vital staining with $1 \%$ brilliant cresyl blue to investigate suspected $\alpha$-thal and unstable Hb. ${ }^{16}$

The newborns were divided into two groups to analyze the hematological parameters of the patients with hemoglobinopathies. The first, named the Normal Group, was composed of newborns with no hemoglobinopathies; and the second, the Case Group, had at least one type of abnormal hemoglobin.

Descriptive analysis, including absolute frequencies and percentages, means and standard deviations was used. The chisquare $\left(\chi^{2}\right)$ test was used to identify significant associations between categorical variables and the Student $t$ test was used to compare the means of hematological variables between the Normal and Case Groups. The significance level was set at 5\%. The hemoglobinopathy incidence rate was calculated by dividing the total number of live births in the hospital by the number of newborns identified with a specific hemoglobinopathy over the course of the study period.

\section{RESULTS}

Out of the 1,004 samples analyzed, 50.1\% were from females and $49.9 \%$ from males. The electrophoresis results were altered in $16.73 \%(n=168)$ of the cases, i.e. abnormal hemoglobins were identified in one in every six newborns (1:6).

The most frequent hemoglobinopathy was $\alpha$-thal $(n=105)$, i.e. one newborn in every 9.6 live births (1:9.6), and 13 of these cases were associated with $\mathrm{Hb} S$ (1:77.2). Sixty-one of the newborns were positive for $\mathrm{Hb} \mathrm{S}$ (1:16.5); 46 were heterozygous (1:21.8), 13 (1:77.2) were associated with $\alpha$-thal and two were homozygous (1:502). Additionally, nine newborns were heterozygous for $\mathrm{Hb} \mathrm{C}(1: 111.6)$ and six were suggestive of beta thalassemia (1:167.3) (Table 1).

There were no significant differences in abnormal hemoglobins with regard to gender or the place of origin of the newborns. However, a significantly higher proportion of Afro-descendants (16.94\%) had abnormal hemoglobins $(\mathrm{P}<0.0001)$ (Table 2$)$.
Table 1. Incidence of hemoglobinopathies as observed through neonatal screening performed between 2011 and 2013 in a hospital in Brazil $(n=1,004)$

\begin{tabular}{lccc|}
\hline Hemoglobinopathy & $\mathbf{N}$ & $\%$ & Prevalence \\
\hline a-thal & 105 & 10.46 & $1: 9.6$ \\
\hline Hb S heterozygote & 46 & 4.58 & $1: 21.8$ \\
\hline a-thal/Hb S heterozygote & 13 & 1.29 & $1: 77.2$ \\
\hline Hb C heterozygote & 9 & 0.9 & $1: 111.6$ \\
$\beta$-thal & 6 & 0.6 & $1: 167.3$ \\
\hline Hb S homozygote & 2 & 0.2 & $1: 502.0$ \\
\hline
\end{tabular}

Table 2. Absolute distribution and percentages of the newborns with normal and abnormal hemoglobins, stratified according to gender, place of origin and ethnicity

\begin{tabular}{|c|c|c|c|c|c|}
\hline & \multicolumn{4}{|c|}{ Hemoglobin profile } & \multirow{3}{*}{ P-value } \\
\hline & \multicolumn{2}{|c|}{$\begin{array}{l}\text { Normal } \\
(n=836)\end{array}$} & \multicolumn{2}{|c|}{$\begin{array}{c}\text { Abnormal } \\
(n=168)\end{array}$} & \\
\hline & No. & $\%$ & No. & $\%$ & \\
\hline \multicolumn{6}{|l|}{ Gender } \\
\hline Male & 419 & 83.63 & 82 & 16.36 & \multirow{2}{*}{0.8217} \\
\hline Female & 417 & 82.90 & 86 & 17.09 & \\
\hline \multicolumn{6}{|l|}{ Place of origin } \\
\hline Uberaba & 682 & 83.78 & 132 & 16.21 & \multirow{3}{*}{0.6667} \\
\hline $\begin{array}{l}\text { Neighboring towns } \\
\text { and surroundings }\end{array}$ & 91 & 81.25 & 21 & 18.75 & \\
\hline Other states and regions & 63 & 80.76 & 15 & 19.23 & \\
\hline \multicolumn{6}{|l|}{ Ethnic background } \\
\hline European descendant & 64 & 85.33 & 11 & 14.66 & \multirow{3}{*}{$<0.0001$} \\
\hline Afro-descendant & 770 & 83.06 & 157 & 16.94 & \\
\hline Unknown & 2 & 100 & 0 & 0.00 & \\
\hline
\end{tabular}

\section{DISCUSSION}

In total, around 1,160 abnormal hemoglobin values and around 300 different types of thalassemia have been described. ${ }^{2,17}$ The process of miscegenation of the Brazilian population resulting from migration is reflected in regional characteristics and is considered to be the main factor in the distribution of abnormal genes in globin chains characteristic of the sickle cell and thalassemia syndromes. The rate of occurrence of these disorders in the Brazilian population as a whole, excluding asymptomatic carriers of $\alpha$-thal, is estimated to be around $4 \%{ }^{7,18}$

As already mentioned, the Brazilian neonatal screening program (which currently uses high-resolution liquid chromatography, HPLC) fails to identify patients with one or two abnormal genes relating to $\alpha$-thal and individuals with $\beta$-thal minor due to high $\mathrm{Hb} \mathrm{F}$ concentrations. This certainly explains the observed low rates of hemoglobinopathies other than $\mathrm{Hb} \mathrm{S}, \mathrm{Hb} C, \mathrm{Hb} \mathrm{D}$ and $\mathrm{Hb}$ $\mathrm{E}$, as presented in official reports and even in some studies. ${ }^{7,18,19}$

The most common hemoglobinopathy in the region of Uberaba, similar to other studies conducted in Brazilian regions 
where there is a predominance of Afro-descendants, has been found to be $\alpha$-thal (1:9.6). ${ }^{10,20,21}$ This differs from the states of Rio Grande do Sul and Paraná, where there are fewer Afrodescendants. ${ }^{13}$ It is known that the most common genotype of $\alpha$-thal in the Brazilian population is the $-\alpha^{3.7}$ deletion, which is directly related to the black population.

The results from a pilot study that investigated the genotypes of 353 newborns in the same institution showed that the incidence of $\alpha$-thal was $10.2 \%$, and that $94.44 \%$ (34/36) of the diagnosed cases had the $-a^{3.7}$ deletion and $5.56 \%$ had the $-a^{4.2}$ deletion. Furthermore, apart from the $-a^{3.7}$ deletion, the great majority $(93.5 \%)$ of the newborns with abnormal hemoglobins were Afro-descendants, which could explain the high prevalence of the $\alpha$-thal found, thereby highlighting the strong influence of this ethnicity on the composition of the population of this region.

An earlier study conducted in Uberaba among patients in the same hospital reported much lower rates of hemoglobinopathies than in the present study, especially in relation to $\alpha$-thal $(0.2 \%)$. This large difference can be explained by the technique that was used (electrophoresis only at alkaline $\mathrm{pH}$ ), given that the focus of the article was $\mathrm{Hb} \mathrm{S}$ disease. ${ }^{22}$ This reinforces the need for an association of different tests in order to detect different hemoglobinopathies, especially electrophoresis at neutral $\mathrm{pH}$ and cytological investigation of $\mathrm{Hb} \mathrm{H}$ inclusion bodies using brilliant cresyl blue, or even molecular testing. Correlation of the results from the present study with those from several other studies on Brazilian populations (rates of between 10 and 20\%) ) $^{23,24}$ shows the reliability of the technique used here.

In Brazil, the occurrences of $\beta$-thal are the result of extensive miscegenation of the Brazilian population with large numbers of Mediterranean immigrants, estimated at about five million, from Europe and Middle East in the nineteenth and twentieth centuries, who settled mainly in the south and southeast of the country. ${ }^{16}$ In this study, the prevalence of $\beta$-thal $(0.60 \%)$ was similar to what had previously been found in other investigations in Brazil (from $0.38 \%$ to $1 \%$ ). ${ }^{25,26}$ However, it was lower than the rate reported by Aigner et al. ${ }^{23}$ (5.50\%) in a study carried out in Paraná, where there is a high proportion of Italian descendants.

In relation to $\alpha$-thal, research using random samples from neonatal screening in the state of Minas Gerais has shown that $30 \%$ of newborns with sickle cell anemia also inherited the $\alpha$-thal gene. ${ }^{27}$ This result is similar to those found in the states of São Paulo (23.7\%), ${ }^{28}$ Bahia (29.1\%) and Pernambuco (25.6\%). ${ }^{10,29}$ In the current study, $21.31 \%$ of the patients with $\mathrm{Hb} \mathrm{S}$ also inherited the $\alpha$-thal gene and therefore the frequency of $\alpha$-thal in the Brazilian population is relatively high, with even higher prevalence among Afro-descendants. ${ }^{20,24,27}$

$\mathrm{Hb} \mathrm{S}$ is considered to be the most prevalent hereditary redblood cell disorder in the world. It causes severe consequences including major hematological changes. This hemoglobin variant manifests in the heterozygous form (Hb AS, sickle cell trait), in the homozygous form (Hb SS, sickle cell anemia) or in combination with other hemoglobinopathies (sickle cell disease)., ${ }^{7,14}$ In Brazil, around one in every thousand newborns is born with sickle cell disease and about 200,000 with the sickle trait, every year. ${ }^{7}$ Among all the newborns with sickle cell disease, around $25 \%$ do not reach the age of five if they are not diagnosed early and treated appropriately. ${ }^{16,18}$

The frequency of $\mathrm{Hb} \mathrm{S}$ observed in this study was $5.87 \%$. Frequencies of the $\mathrm{Hb} \mathrm{S}$ gene of $4.35 \%$ and $5.88 \%$ have been reported among newborns in the states of Minas Gerais and Bahia. ${ }^{7,18}$ This is certainly related to the high prevalence of blacks in the composition of the population in the region of the present study, where only $7.5 \%$ of the mothers did not report black ancestry within their previous two generations.

Two cases of sickle cell anemia (Hb SS) were identified in this study, giving an prevalence of 1:502 newborns. In Bahia, the frequency of the SS genotype was 1:650. These frequencies vary widely according to the degree of racial admixture in the different regions of Brazil. ${ }^{10}$ Since the data from the municipal Health Department of Uberaba show that the prevalence of sickle cell disease in the region in 2012 was 1:1166, the high rate observed in the current study may be due to the small sample size and also to the fact that one of the infants with $\mathrm{Hb}$ SS was from a neighboring town (Delta). This child's parents were from northeastern Brazil, and were Afro-descendants who had migrated to work in the sugar cane plantations of the region. Similar to $\mathrm{Hb} \mathrm{S,} \mathrm{Hb} \mathrm{C}$ is characteristic of blacks: in Africa, the frequencies range from 5 to $25 \%$, depending on the region. In the present study, the prevalence of $\mathrm{Hb} \mathrm{C}(0.9 \%)$ was similar to that found in other Brazilian studies, thus reinforcing the influence of African people on the formation of the local population. ${ }^{6,10,23,30}$

Although no significant differences were found between the three groups separately, comparison of the prevalence of hemoglobinopathies among whites of European ancestry with the prevalence among Afro-descendants showed a highly significant difference $(P<0.0001)$. This again reinforces the importance of the ethnic composition of the population of this region. ${ }^{18,22,27,30}$

Hemoglobinopathies are diagnosed through identifying abnormal hemoglobins in the laboratory. Unlike other hemoglobins, $\mathrm{Hb} \mathrm{A}_{2}$ needs to be measured using analytical methods that provide greater precision, given that the diagnosis of $\beta$-thal minor depends on these values. Individuals with $\beta$-thal minor have levels that, on average, are 1-2\% above the reference values for $\mathrm{Hb} \mathrm{A}_{2} \cdot{ }^{24}$

In accordance with the Brazilian Ministry of Health Protocol, all newborns diagnosed with structural hemoglobinopathies and thalassemia by means of screening tests should be reassessed 
after reaching six months of age, using tests to confirm the result. However, many infants are not brought back for the tests to be repeated for diagnostic confirmation, and active searches are not always successful. ${ }^{7}$ Moreover, the diagnostic difficulties in the post-neonatal period are well known, especially those relating to the most prevalent forms of $\alpha$-thal, with deletions of only one or two genes. This is due to the absence of clinical manifestations and the mild laboratory abnormalities, ${ }^{3,4}$ or due to diagnostic failures mainly because of technical ineptitude and low concentrations of $\mathrm{Hb} \mathrm{H}$, as is the case of the interaction of $\alpha$-thal and $\beta$-thal. ${ }^{24}$ However, in this study, similar to others, ${ }^{10,20,27,30}$ cases suggestive of $\alpha$-thal were more common than were cases of heterozygous $\mathrm{Hb} \mathrm{S}$, which is a characteristic of Afro-descendants, hence demonstrating the efficiency of the methods used here.

The prevalence of hemoglobinopathies observed in this study $(16.73 \%)$ is consistent with what has been reported worldwide, and with findings from other regions of Brazil, like in the southeast and northeast (between $6.84 \%$ and 18.98\%). ${ }^{13,20,24}$ However, in other Brazilian studies, frequencies of hemoglobinopathies of between 0.98\% and 3.54\% were found..$^{19,25,31}$ The possible explanations for this great variability in the frequency of hemoglobinopathies are the wide ethnic diversity of the populations studied and the different diagnostic methodologies used. $3,7,10,20,32$

Application of more than one method in the initial screening enhances the specificity and proves to be useful for detecting patients with hemoglobinopathies. The screening methods are easy to perform, inexpensive and reproducible in routine practice in laboratories. However, application of these tests separately is unreliable and not recommended for the majority of hemoglobinopathies, which highlights the need to use complementary molecular techniques, especially for $\alpha$-thal in cases of association with other hemoglobinopathies. ${ }^{5,12,16,24,26}$

\section{CONCLUSION}

In summary, this study shows that the frequency of hemoglobinopathies was $16.73 \%$, and that $\alpha$-thal was the most frequent of these (10.46\%). We also observed that the Afro-descendant newborns had a higher proportion of abnormal hemoglobin (16.94\%, $\mathrm{P}<0.0001)$. Hemoglobinopathies are a public health problem in Brazil, and these findings are corroborated by data from the National Neonatal Screening Program for diagnosing sickle cell disease and $\mathrm{Hb}$ C, $\mathrm{Hb} \mathrm{D}, \mathrm{Hb} \mathrm{E}$ and $\beta$-thal hemoglobinopathies.

\section{REFERENCES}

1. Traeger-Synodinos J, Vrettou C, Kanavakis E. Prenatal, noninvasive and preimplantation genetic diagnosis of inherited disorders: hemoglobinopathies. Expert Rev Mol Diagn. 2011;11(3):299-312.

2. Higgs DR. The molecular basis of $\boldsymbol{\alpha}$-thalassemia. Cold Spring Harb Perspect Med. 2013;3(1):a011718.
3. Weatherall DJ. The role of the inherited disorders of hemoglobin, the first "molecular diseases," in the future of human genetics. Annu Rev Genomics Hum Genet. 2013;14:1-24.

4. Weatherall DJ, Clegg JB. Inherited haemoglobin disorders: an increasing global health problem. Bull World Health Organ. 2001;79(8):704-12.

5. Weatherall D. Thalassemia: the long road from the bedside through the laboratory to the community. Nat Med. 2010;16(10):1112-5.

6. Aimiumu E, Thomas A, Roheemun N, et al. A guide for the haemoglobinopathy nurse. Nicósia: Thalassaemia International Federation; 2013. Available from: http://www.thalassaemia.org.cy/ wp-content/uploads/pdf/about-hb-disorders/NURSE\%20GUIDE\%20 BOOKLET\%20v.04.pdf. Accessed in 2015 (Mar 12).

7. Brasil. Ministério da Saúde. Secretaria de Atenção a Saúde. Departamento de Atenção Especializada. Doença falciforme: condutas básicas para tratamento. Brasília: Ministério da Saúde; 2012. Available from: http://bvsms.saude.gov.br/bvs/publicacoes/doenca_ falciforme_condutas_basicas.pdf. Accessed in 2015 (Mar 12).

8. Núcleo de Ações e Pesquisa em Apoio Diagnóstico (NUPAD). Doença falciforme. Available from http://www.nupad.medicina.ufmg br/?page_id=1871--. Accessed in 2015 (Aug 21).

9. Souza AE, Cardoso GL, Takanashi SY, Guerreiro JF. Alpha-thalassemia (3.7 kb deletion) in a population from the Brazilian Amazon region: Santarém, Pará State. Genet Mol Res. 2009;8(2):477-81.

10. Adorno EV, Couto FD, Moura Neto JP, et al. Hemoglobinopathies in newborns from Salvador, Bahia, Northeast Brazil. Cad Saude Publica. 2005;21(1):292-8.

11. Melo-Reis PR, Naoum PC, Diniz-Filho JAF, et al. Prevalência de talassemias e hemoglobinas variantes no estado de Goiás, Brasil [Prevalence of thalassemias and variant hemoglobins in the state of Goiás, Brazil]. J Bras Patol Med Lab. 2006;42(6):425-30.

12. Melo LMS, Siqueira FAM, Conte ACF, Domingos CRB. Rastreamento de hemoglobinas variantes e talassemias com associação de métodos de diagnóstico [Tracking of variant hemoglobins and thalassemias by association of diagnosis methodologies]. Rev Bras Hematol Hemoter. 2008;30(1):12-7.

13. Seixas FAV, Silva CD, Tominaga J, Ferro OC, Nilson LG. Incidência de hemoglobinopatias no noroeste do Paraná - Brasil [Incidence of hemoglobinopathies in Northwest Paraná, Brazil]. Rev Bras Hematol Hemoter. 2008;30(4):287-91.

14. Martins PRJ, Moraes-Souza H, Silveira TB. Morbimortalidade em doença falciforme [Morbidity-mortality in sickle cell disease]. Rev Bras Hematol Hemoter. 2010;32(5):378-83.

15. Brasil. Instituto Brasileiro de Geografia e Estatística (IBGE). Características étnico-raciais da população. Um estudo das categorias de classificação de cor ou raça 2008. Rio de Janeiro: Instituto Brasileiro de Geografia e Estatística; 2011. Available from: http://biblioteca.ibge.gov.br/visualizacao/livros/liv49891.pdf. Accessed in 2015 (Aug 17). 
16. Naoum PC. Distribuição Geográfica das Hemoglobinopatias. In: Naoum PC. Diagnóstico das hemoglobinopatias. São Paulo: Sarvier, 1987. p. 143-50.

17. Globin Gene Server. HbVar: A database of human hemoglobin variants and thalassemias. Available from: http://globin.cse.psu.edu/ globin/hbvar. Accessed in 2015 (Mar 13).

18. Zago MA. Anemia falciforme e doenças falciformes. In: Brasil. Ministério da Saúde. Secretaria de Políticas de Saúde. Manual de doenças mais importantes, por razões étnicas, na população brasileira afro-descendente. Brasília: Ministério da Saúde; 2001. p. 13-35. Available from: http://bvsms.saude.gov.br/bvs/publicacoes/ doencas_etnicas.pdf. Accessed in 2015 (Mar 13).

19. Sommer CK, Goldbeck AS, Wagner SC, Castro SM. Triagem neonatal para hemoglobinopatias: experiência de um ano na rede de saúde pública do Rio Grande do Sul, Brasil [Neonatal screening for hemoglobinopathies: a one-year experience in the public health system in Rio Grande do Sul State, Brazil]. Cad Saude Publica. 2006;22(8):1709-14.

20. Viana-Baracioli LMS, Bonini-Domingos CR, Pagliusi RA, Naoum PC. Prevenção de hemoglobinopatias a partir do estudo em gestantes [Hemoglobinopathies: a study in pregnancy]. Rev Bras Hematol Hemoter. 2001;23(1):31-9.

21. Ducatti RP, Teixeira AEA, Galão HA, Bonini-Domingos CR, Fett-Conte AC. Investigação de hemoglobinopatias em sangue de cordão umbilical de recém-nascidos do Hospital de Base de São José do Rio Preto [Hemoglobinopathies in new-born cord blood of the Hospital de Base de São José do Rio Preto]. Rev Bras Hematol Hemoter. 2001;23(1):23-9

22. Campos LMFR, Dias FL, Mendes M. Hemoglobinas anormais em sangue de cordão umbilical [Abnormal hemoglobins in umbilical cord blood]. Rev Bras Hematol Hemoter. 2006;28(1):67-9.

23. Aigner CP, Sandrini F, Duarte EG, etal. Estudo do perfil de hemoglobinas em 9.189 testes realizados no Alvaro Centro de Análises e Pesquisas Clínicas [The characteristic of 9,189 tests of hemoglobinopathy diagnostic from the Alvaro Center of Clinical Chemistry and Research in the 2004 year]. Rev Bras Anal Clin. 2006;38(2):107-9.

24. Naoum PC, Bonini-Domingos CR. Dificuldades no diagnóstico laboratorial das hemoglobinopatias [Dificulties on the laboratorial diagnosis of hemoglobinopathies]. Rev Bras Hematol Hemoter. 2007;29(3):226-8.

25. Martini G, Bastos BM, Santos N, et al. Triagem neonatal e hemoglobinopatias em Santa Catarina, Brasil [Neonatal screening and hemoglobinopathies of Santa Catarina, Brazil]. Rev Bras Anal Clin. 2009;41(3):185-9.

26. Orlando GM, Naoum PC, Siqueira FAM, Bonini-Domingos CR. Diagnóstico laboratorial de hemoglobinopatias em populações diferenciadas. Rev Bras Hematol Hemoter. 2000;22(2):111-21.

27. Belisário AR, Viana MB. Efeitos da Talassemia Alfa nas manifestações clínicas e hematológicas da Anemia Falciforme: uma revisão sistemática [Effects of alpha-thalassemia on the clinical and hematologic manifestations of sickle cell anemia: a systemic review]. Rev Méd Minas Gerais. 2011;21(3): 312-21.

28. Lima CS, Rocha EM, Silva NM, et al. Risk factors for conjunctival and retinal vessel alterations in sickle cell disease. Acta Ophthalmol Scand. 2006;84(2):234-41.

29. Bezerra MA, Santos MN, Araújo AS, et al. Molecular variations linked to the grouping of beta- and alpha-globin genes in neonatal patients with sickle cell disease in the State of Pernambuco, Brazil. Hemoglobin. 2007;31(1):83-8.

30. Sonati MF, Kimura EM, Grotto HZ, Gervasio SA, Costa FF. Hereditary hemoglobinopathies in a population from southeast Brazil. Hemoglobin. 1996;20(2):175-9.

31. Vespoli S, Marques M, Marane SSG, et al. Análise das prevalências de doenças detectadas pelo programa nacional de triagem neonatal no município de Araraquara no ano de 2009. Rev Ciênc Farm Básica Apl. 2011;32(2):269-73.

32. Mendes LC, Santos TT, Bringel FA. Evolução do programa de triage neonatal no estado do Tocantins [Evolution of the neonatal screening program in the state of Tocantins]. Arq Bras Endocrinol Metabol. 2013:57(2):112-9.

Sources of funding: The authors are grateful for the financial support from FAPEMIG (Fundação de Amparo à Pesquisa do Estado de Minas Gerais) and CAPES (Coordenação de Aperfeiçoamento de Pessoal de Nível Superior)

Conflict of interest: None

Date of first submission: January 11, 2015

Last received: February 18, 2015

Accepted: February 23, 2015

\section{Address for correspondence:}

Professor Helio Moraes de Souza

Departamento de Clínica Médica, Universidade Federal do Triângulo Mineiro (UFTM) and Fundação Hemominas

Av. Getúlio Guaritá, 250

Abadia — Uberaba (MG) — Brasil

CEP 38025-440

Tel. (+ 55 34) 3318-5560

Fax. (+55 34) 3312-5077

E-mail: helio.moraes@dcm.uftm.edu.br 